\title{
Znanstveni premislek o psihofiziološkem ugotavljanju zavajanja
}

\author{
Igor Areh $^{1 *}$ in Kaja Jaklin ${ }^{2}$ \\ ${ }^{1}$ Fakulteta za varnostne vede, Univerza v Mariboru \\ ${ }^{2}$ Ljubljana
}

Povzetek: Zanimanje za psihofiziološko ugotavljanje zavajanja se je v zadnjem desetletju povečalo, kar je povezano s povečanimi varnostnimi tveganji, s katerimi se soočamo. Članek razpravlja o primernosti uporabe poligrafa pri preiskovanju kaznivih dejanj z vidika znanosti, predvsem psihologije. Predstavlja, oceni in primerja dve najbolj uporabljeni tehniki ugotavljanja zavajanja: Test primerjalnih vprašanj (CQT) in Test prikritih informacij (CIT). Pri obeh tehnikah preuči njuno teoretično ozadje, objektivnost in standardiziranost testnih postopkov, točnost (veljavnost) tehnik ter predstavi etične in druge praktične pomisleke. Test primerjalnih vprašanj po desetletjih raziskav in razvoja ni razrešil svojih temeljnih težav in omejitev. Ostaja neznanstven in nestandardiziran test, ki si ločen od znanosti niti ne prizadeva k izhodu iz slepe ulice. Članek predstavi vplivnejše teorije, na katerih skušajo zagovorniki utemeljiti poligrafsko testiranje. Kritična analiza kaže, da nobena od teorij ne predstavlja zadovoljivega teoretičnega temelja tehnike. Zaradi odsotnosti znanstveno-teoretične utemeljitve ostaja tehnika primerjalnih vprašanj sporna in ujeta $\mathrm{v}$ samozadostnost. Ta se napaja predvsem iz metodološko vprašljivih raziskovalnih ugotovitev zagovornikov tehnike. Nasprotno pa tehnika prikritih informacij doživlja raziskovalni razcvet, predvsem na področju nevrologije, in velja za etično manj sporno in delno znanstveno utemeljeno s teorijo orientacijskega odziva. $\mathrm{Z}$ njo se nekoliko naivno in sporno ugotavljanje laži nadomešča z iskanjem podatkov, ki so prikriti v spominu testirancev. A tudi ta tehnika ima resne pomanjkljivosti in omejitve, zaradi katerih se postavlja vprašanje o smiselnosti uporabe poligrafa pri ugotavljanju zavajanja.

Ključne besede: poligraf, tehnika primerjalnih vprašanj (CQT), tehnika prikritih informacij (CIT), zavajanje, objektivnost

\section{Scientific review of psychophysiological detection of deceit}

\author{
${\text { Igor } \text { Areh }^{1 *} \text { and Kaja Jaklin }}^{2}$ \\ ${ }^{1}$ Faculty of Criminal Justice and Security, University of Maribor, Slovenia \\ ${ }^{2}$ Ljubljana, Slovenia
}

\begin{abstract}
Psychophysiological detection of deceit has been in the centre of attention in the recent decade, which correlates with heightened security challenges of a modern world. The article provides scientific discussion about polygraph that is used in criminal investigation. Two most employed polygraph techniques are critically presented, examined and compared: the Comparison Question Test (CQT) and the Concealed Information Test (CIT). Theoretical foundations, objectivity and standardization of testing procedures, ethical and practical issues are analysed. Proponents of the Comparison Question Test have not been successful in their efforts to resolve fundamental problems and limitations with which the technique is challenged. It remains unstandardized and unscientific, separated from science and mainly without attempts to escape from the dead-end. The most influential theoretical backgrounds of CQT technique are examined; however, none of them represents a satisfactory scientific foundation of the technique. Without being scientifically grounded in a verifiable theory, it remains controversial and caught into self-sufficiency, mostly supported by methodologically questionable research findings gained by proponents. To the contrary, the Concealed Information Test is associated with fast development, particularly in the field of neurology, and is considered to be less disputed and to be partly supported by a sound scientific ground. Applying the Concealed Question Test, somewhat naïve and disputable detection of lies typical of the Comparison Question Test is replaced by a search for information that lies concealed in the suspects' memory. However, the Concealed Information Test also has been challenged by serious deficiencies, which bring forward a question about justification of the use of the polygraph.
\end{abstract}

Keywords: polygraph, Comparison Question Test (CQT), Concealed Information Test (CIT), deceit, objectivity

\footnotetext{
*Naslov/Address: dr. Igor Areh, Fakulteta za varnostne vede, Univerza v Mariboru, Kotnikova 8, 1000 Ljubljana, e-pošta: igor.areh@gmail.com
}

Članek je licenciran pod pogoji Creative Commons Attribution 4.0 International licence (CC-BY licenca).

The article is licensed under a Creative Commons Attribution 4.0 International License (CC-BY license). 
Zanimanje raziskovalcev za psihofiziološko ugotavljanje zavajanja se je v zadnjem desetletju zelo povečalo, kar je verjetno posledica povečanih potreb varnostnih služb po odkrivanju storilcev kaznivih dejanj, še posebno v sklopu boja proti terorizmu (Rosenfield, Ben-Shakhar in Ganis, 2012). V grobem lahko metode psihofiziološkega ugotavljanja laži razdelimo v dve skupini; v prvi so metode, ki temeljijo na analizi fizioloških odzivov osumljencev na neposredna vprašanja, $\mathrm{v}$ drugi pa metode za ugotavljanje obstoja informacij ali spominov, ki jih testirane osebe skušajo prikriti (Ben-Shakhar, 2012). Tipičen predstavnik prve skupine je test primerjalnih vprašanj (Comparison Questions Test - CQT, v preteklosti bolj poznan kot Control Question Technique), ki velja za najbolj uporabljano tehniko ugotavljanja laži. V drugi skupini je najbolj prepoznavna tehnika $\mathrm{z}$ imenom test prikritih informacij (Concealed Information Test - CIT, v preteklosti Guilty Knowledge Test - GKT), ki ni tako sporna kot test primerjalnih vprašanj, saj ima verodostojnejše znanstvene temelje. Pregledovanje področja psihofiziološkega odkrivanja zavajanja kaže, da v zadnjih dvajsetih letih izrazito prevladujejo raziskovalne dejavnosti, povezane $\mathrm{z}$ razvojem tehnik, ki temeljijo na testu prikritih informacij. Kaže, da se je težišče raziskav preneslo s področja testa primerjalnih vprašanj na raziskovanje ugotavljanja zavajanja $\mathrm{s}$ testom prikritih informacij.

V okviru obeh naštetih skupin tehnik ali metod psihofiziološkega ugotavljanja zavajanja se uporabljajo različni testi, ki temeljijo na domnevi, da so odzivi lažnivcev drugačni kot odzivi iskrenih oseb. Zlasti za testiranje $\mathrm{z}$ uporabo tehnike CQT velja, da je oblikovano tako, da spodbudi pojav strahu. Zato je težko reči, da z njim ugotavljamo laži. Bolj verjetno je, da z njimi merimo raven doživetega strahu oziroma anksioznosti, ki pa ne more biti pokazatelj zavajanja. Ugotavljanje laži namreč ne more temeljiti na ugotavljanju povišane stopnje vznemirjenosti, saj ne obstaja psihofiziološki odziv, ki bi bil neposredno povezan z laganjem ali zavajanjem (Vrij, 2008). A namesto spornega ugotavljanja laganja lahko ugotavljamo, ali oseba razpolaga $\mathrm{s}$ ključnimi informacijami, saj se ob soočenju z njimi pojavijo specifični psihofiziološki odzivi. Tako ugotavljamo stopnjo verjetnosti, da je posameznik seznanjen s ključnimi podatki in verjetno povezan $\mathrm{z}$ dogodkom, ki ga preiskuje policija.

V Združenih državah Amerike je poligrafija najrazvitejša, najbolj uporabljana in sprejeta. Po letu 1993 so sodišča v ZDA poostrila merila sprejemljivosti dokazov in po sedanjih kriterijih nobena poligrafska tehnika ne izpolnjuje vseh meril znanstvene sprejemljivosti dokazov (National Research Council [NRC], 2003). Tako je poligrafski izvid le pogojno dopusten kot dokazno gradivo v 20 ameriških zveznih državah, na zvezni ravni pa načeloma ne več (Vigluicci, 2009).

V ZDA uporabljajo poligrafsko testiranje za presojanje resničnosti izjav osumljencev, za preverjanje zaposlenih $\mathrm{v}$ organih zagotavljanja državne varnosti (Handler, Honts, Krapohl, Nelson in Griffin, 2009), za preverjanje pogojno izpuščenih spolnih prestopnikov (Jensen, Shafer, Roby in Roby, 2014) in ponekod za preverjanje kandidatov za zaposlitev v policiji ter drugih agencijah državne varnosti (Handler idr., 2009). Poligrafsko testiranje zaposlenih in kandidatov za zaposlitve $\mathrm{v}$ zasebnem sektorju je od leta 1988 naprej prepovedano (NRC, 2003). Takšna uporaba poligrafskega testiranja je namreč sporna zaradi vprašljive točnosti poligrafa, ko ga uporabljamo za testiranje zaposlenih. Verodostojnih in nepristranskih študij, ki bi pokazale točnost poligrafiranja tistih, ki niso osumljenci, namreč ni. To pomeni, da točnost poligrafa ni preverjena izven konteksta policijskega preiskovanja, zato ga je neprimerno uporabljati za drugačne namene (British Psychological Society [BPS], 2004).

V Evropi se poligrafski testi za ugotavljanje laži uporabljajo v Belgiji in na Finskem (Meijer in Verschure, 2010), na Norveškem (Canter in Žukauskiene, 2008), Poljskem in v Romuniji (Areh, 2011). Poligraf je ponekod popolnoma zavrnjen, kot na primer v Švici, kjer je njegova uporaba nezakonita zaradi spoštovanja Evropske konvencije o človekovih pravicah, ki jo tamkajšnja sodišča razlagajo tako, da nihče ne sme biti prisiljen posredno ali neposredno obtožiti samega sebe (Schmid, 1993). Podobno velja za Nemčijo, kjer je leta 1998 vrhovno sodišče zavrnilo uporabo tehnike CQT (Fiedler, Schmid in Stahl, 2002). V Veliki Britaniji so opustili uporabo poligrafa $\mathrm{v}$ preiskovanju kaznivih dejanj, ga pa uporabljajo pri nadzorovanju spolnih prestopnikov (Meijer in Verschure, 2010). V Sloveniji se poligraf uporablja kot usmerjevalno orodje pri preiskovanju kaznivih dejanj, poligrafske ugotovitve pa nimajo dokazne vrednosti (Areh, 2011). Če povzamemo, poligrafsko testiranje se uporablja predvsem v predkazenskih postopkih, ugotovitve testiranja pa praviloma nimajo dokazne vrednosti v sodnih postopkih. Pri slednjem so izjema ZDA, Belgija, Izrael in Japonska, kjer so rezultati poligrafskega testiranja pogojno lahko uporabljeni kot dokazno gradivo na sodišču (Ganapati, Haveripeth in Ramadurg, 2013). Razlogov za zavrnitev poligrafa v Evropi je več, najdemo jih v njegovi znanstveni spornosti, kršenju etičnih in zakonskih normativov, a o tem več v nadaljevanju. V članku sta kritično predstavljeni dve najpogosteje uporabljeni poligrafski metodi; test s primerjalnimi vprašanji (CQT) in test prikritih informacij (CIT). Opisana sta najbolj uveljavljena postopka uporabe poligrafa, preučeni so znanstveno teoretični temelji poligrafa, točnost, standardiziranost in objektivnost poligrafskih meritev.

\section{Test s primerjalnimi vprašanji (CQT)}

Pri preiskovanju kaznivih dejanj je to najpogosteje uporabljen poligrafski test, ki je navadno sestavljen iz petih ali šestih faz. V prvi fazi, ki poteka pred intervjujem, skuša poligrafist pridobiti podatke o osumljencu in zločinu, predstaviti obtožbe, vzpostaviti občutek nepristranskosti in zaupanja ter pojasniti delovanje poligrafa (Raskin in Honts, 2002). Sledi druga faza $z$ uporabo stimulacijskega testa. Njen namen je preiskovanca prepričati v nezmotljivost poligrafa. Pri stimulacijskem testu se pogosto uporabljajo igralne karte. Preiskovanec si izbere karto iz seta kart, si jo zapomni in jo vrne med druge karte. Poligrafist nato preiskovancu pokaže več kart in vsakič vpraša, ali je bila to njegova izbrana karta, še pred tem pa mu naroči, naj vedno odgovori $\mathrm{z} » \mathrm{Ne} \ll$. Poligrafist preveri rezultate testiranja in preiskovancu pove, katero karto 
je izbral in pri tem se ne sme zmotiti, saj bi s tem izničil iluzijo nezmotljivosti poligrafa (Raskin in Honts, 2002). Zato poligrafisti včasih skrivaj označijo pravo karto (Reid in Inbau, 1977), ali uporabijo set enakih kart (Bashore in Rapp, 1993). Poligrafisti skušajo osumljenca prepričati o popolnosti metode tudi z ustvarjanjem vtisa pomembnosti in kompetentnosti, kar počno npr. s poslovno obleko in razkazovanjem priznanj, certifikatov in fotografij s pomembnimi ljudmi (Bull, 1988). Gre za uporabo tehnik socialnega vplivanja, katerih namen je psihološka manipulacija z obravnavanimi osebami (glej Cialdini, 2001).

$\mathrm{V}$ tretji fazi poligrafist oblikuje vprašanja, ki jih bo uporabil med testom, in se o njih pogovori s testirano osebo. Ločimo tri vrste vprašanj: nevtralna, relevantna in kontrolna. Nevtralna vprašanja so splošna (npr. »Ali je danes petek?«) in imajo vlogo mašil, fiziološki odzivi nanje se ne upoštevajo. Relevantna vprašanja so povezana s kaznivim dejanjem (npr.: »Ali ste ukradli Renault Megan?«). Kontrolna vprašanja so le posredno povezana s kaznivim dejanjem in so splošna. Oblikovana so tako, da odgovor »Ne« pomeni laž, npr.: »Ali ste do 25. leta starosti kdaj vzeli kaj, kar ni bilo vaše?« V vsakdanjem pogovoru bi testirana oseba verjetno priznala, da je nekoč vzela nekaj, med poligrafskim testiranjem pa je to manj verjetno. Poligrafist bi namreč zaradi priznanja lahko sklepal, da je oseba že kradla in to bi potrdilo sum o krivdi. Tako večina preiskovancev na takšna vprašanja odgovori z »Ne« (Raskin in Honts, 2002). Poligrafisti očitne odzive na kontrolna vprašanja tolmačijo kot iskrene, a preiskovancem tega ne povedo. Pri nedolžnih je fiziološki odziv na kontrolna vprašanja močnejši kot na relevantna vprašanja. Pri krivih pa kontrolna vprašanja izzovejo šibkejši odziv kot relevantna vprašanja. Relevantna vprašanja jim namreč predstavljajo resnejšo grožnjo, tako so ob soočenju z njimi bolj vznemirjeni (Raskin in Honts, 2002). A pri oblikovanju kontrolnih vprašanj se pojavlja težava, ker preiskovančevi odgovori na ta vprašanja niso zagotovo, ampak le verjetno laži (Lykken, 1998). Poligrafist tako le domneva, da so preiskovančevi odgovori na kontrolna vprašanja laži.

Četrta faza poligrafiranja je testiranje. Priporočljivo je, da se izvaja v tihi sobi, kjer poligrafist postavlja vprašanja na 2535 sekund, medtem pa se beležijo fiziološki odzivi testiranca (Raskin in Honts, 2002). V peti fazi se interpretira rezultate testiranja, za kar se uporabljata splošni in numerični pristop. Pri splošnem pristopu si poligrafist ustvari splošen vtis o preiskovančevih fizioloških odzivih. Ta vtis je odvisen tudi od drugih pridobljenih podatkov (npr. podatkov iz kazenske evidence) in od preiskovančevega vedenja med testiranjem. $\mathrm{Na}$ podlagi vsega tega poligrafist sprejme odločitev o resničnosti ali neresničnosti izjav preiskovanca (Raskin in Honts, 2002). Uporablja se lahko tudi numerični pristop vrednotenja odzivov, ki pomeni bolj sistematično in objektivno presojanje fizioloških reakcij (primerjajo se odzivi na pare kontrolnih in relevantnih vprašanj). Obstaja tudi šesta, neuradna faza testiranja, v kateri poligrafist po končanem testiranju osumljenca sooči s trditvijo, da laže, in ga vpraša, kako lahko pojasni takšen rezultat testiranja. Poligrafist nato zapusti prostor in skrivaj opazuje osumljenčevo vedenje. Če meni, da vedenje osumljenca nakazuje laganje, lahko to uporabi pri interpretaciji rezultatov in pri nadaljnjem zasliševanju. Namen te faze je pridobiti priznanje (Lykken, 1998).

\section{Znanstvena presoja tehnike primerjalnih vprašanj}

\section{Znanstveno-teoretična utemeljitev tehnike}

Poligrafsko testiranje temelji na dveh domnevah; (i) iskrenost in zavajanje zanesljivo izzoveta različna psihološka stanja pri vseh testiranih osebah in (ii) fiziološki odzivi se pri vseh osebah zanesljivo razlikujejo glede na njihova psihološka stanja. Tako so primerjalna (kontrolna) vprašanja oblikovana tako, da izzovejo pričakovane lažne in iskrene psihofiziološke odzive, ki jih primerjamo $z$ odzivi na relevantna vprašanja, $s$ čimer naj bi ugotovili zavajanje ali iskrenost.

Prvotne teoretične utemeljitve delovanja poligrafa so predvidevale, da so fiziološki odzivi, ki so povezani $\mathrm{z}$ zavajanjem ali strahom pred razkritjem zavajanja, prisilni oz. izven zavestnega nadzora in bistveno intenzivnejši $v$ primerjavi z drugimi znaki anksioznosti, ki se pojavljajo pri testiranju (npr. Larson, 1922). Pri osebah, ki zavajajo, so relevantna vprašanja bolj stimulativna kot primerjalna vprašanja, zato je poligrafski test zelo občutljiv prirazlikovanju med iskrenimi in zavajajočimi odzivi. Takšna teoretična predpostavka tudi pomeni, da je poligrafski test neobčutljiv za protiukrepe. A raziskave kažejo, da ta predvidevanja ne držijo. Natančneje, ni verodostojnih študij, ki bi potrjevale domnevo, da so za lažnivce relevantna vprašanja bolj stimulativna kot primerjalna vprašanja. Podobno velja tudi za nedolžne osebe; domneva, da so primerjalna vprašanja enako ali bolj stimulativna kot relevantna vprašanja, empirično ni potrjena (Iacono in Lykken, 2002; NRC, 2003). Raziskave tudi jasno kažejo, da psihofiziološki odzivi, ki bi bili pokazatelji zavajanja, ne obstajajo (glej Lykken, 1998; Vrij, 2008). Tako lahko sklepamo, da se opazni odzivi na relevantna vprašanja lahko pojavijo, če vprašanja npr. vzbudijo občutek ogroženosti, strahu, jeze ali krivde zaradi nekega dogodka iz preteklosti. Psihofiziološki odzivi v takih primerih niso povezani $\mathrm{z}$ zavajanjem, ampak $\mathrm{z}$ vznemirjenjem, ki ni povezano z laganjem. Razlaga rezultatov merjenja, ki govori o zavajanju osumljenca, je tako lahko povsem napačna.

Poskusi utemeljitve uvodoma omenjenih domnev (da zavajanje in iskrenost izzoveta različna psihološka stanja in da se fiziološki odzivi razlikujejo pri vseh ljudeh, glede na to, v kakšnem psihološkem stanju so), so vidni v kar nekaj teorijah. Za vse teoretične utemeljitve pa velja, da nobena ni empirično dovolj preizkušena, da bi jo bilo mogoče sprejeti ali potrditi. Med starejše in bolj uveljavljene sodi teorija pogojnega odziva, po kateri imajo relevantna vprašanja vlogo pogojnega dražljaja (Davis, 1961). Relevantna vprašanja pri lažnivcih izzovejo privzgojeni (naučeni) čustveni in fiziološki odziv, s katerim naj bi bilo povezano laganje. Ko je kriva oseba $\mathrm{z}$ relevantnim vprašanjem soočena s podrobnostjo zločina, to relevantno vprašanje deluje kot pogojni dražljaj in izzove odziv avtonomnega živčnega sistema ali pogojni čustveni odziv. Pri nedolžnih osebah, ki ne poznajo podrobnosti zločina, relevantno vprašanje ne more delovati kot pogojni dražljaj in zato ne izkažejo pogojenega čustvenega odziva.

A $\mathrm{s}$ to teorijo ne pridemo prav daleč pri utemeljevanju delovanja poligrafa, čeprav je videti, da so odzivi avtonomnega živčnega sistema zares lahko klasično pogojevani (npr. 
LeDoux, 1995). Laganje namreč ni edini možni sprožilec odziva avtonomnega živčnega sistema. Nedolžna oseba lahko izkaže pogojni čustveni odziv (npr. strah) zaradi neke specifične posebnosti relevantnega vprašanja ali načina postavitve vprašanja. Oboje je lahko skrito in neopazno za poligrafista in opazovano osebo. Tako lahko npr. pri nedolžnih pride do odziva zaradi spomina na pretekla zaslišanja, ko so bili neutemeljeno obtoženi. V takem primeru relevantno vprašanje odigra vlogo pogojnega dražljaja, ki izzove npr. jezo, strah ali presenečenje. Podobno se lahko zgodi tudi nedolžnim osebam, ki so doživele stresno oz. travmatično izkušnjo. Relevantno vprašanje lahko sproži pogojni čustveni odziv samo zato, ker je nedolžna oseba $\mathrm{z}$ relevantnim vprašanjem soočena s stresnim spominom. Fiziološki odziv je tako zabeležen, a ni povezan z zavajanjem. Interpretacija takih odzivov je zato napačna, teorija pogojnega odziva pa nezadosten temelj za razlago delovanja poligrafa.

Zagovorniki so skušali uporabnost poligrafa teoretično utemeljili tudi s teorijo psihološkega seta, ki se je začela uveljavljati v začetku 60. let 20. stoletja (glej Senter, Weatherman, Krapohl in Horvath, 2010). Teorija predvideva, da zavajajoča oseba pričakuje negativne posledice ali kazen ob razkritju zavajanja, zato se pri laganju pojavi izmerljiv fiziološki odziv (npr. povečano znojenje oz. električna prevodnost kože). Ali nekoliko drugače, če oseba pričakuje, da obstaja velika verjetnost, da bo zalotena pri zavajanju in da temu sledijo resne posledice, potem občutek ogroženosti sproži fiziološki odziv. Ker so posledice laganja na primerjalna (kontrolna) vprašanja manj resne kot posledice laganja na relevantna vprašanja, so odzivi na slednja bolj intenzivni. A lahko se vprašamo, kaj se zgodi, če se nedolžna oseba boji neupravičene obtožbe, ali če meni, da lahko pride do napake pri merjenju oz. pri delovanju opreme? Povsem verjetno je, da v takem primeru nedolžna oseba intenzivneje odreagira na relevantna vprašanja, saj lahko predvideva, da gre za vprašanja, povezana $\mathrm{z}$ zločinom. Teorija psihološkega seta tako vključuje tudi možnost napake interpretacije testnih rezultatov in je zato šibek teoretični temelj poligrafije.

Nekateri (npr. Kleiner, 2002) skušajo delovanje tehnike primerjalnih vprašanj (CQT) utemeljiti tudi $\mathrm{s}$ teorijo orientacijskega odziva (Pavlov, 1927/2003). Orientacijski odziv se pojavi po zaznavi novega ali osebno pomembnega dražljaja in sproži prilagoditveni vedenjski odziv (Sokolov, 1963), kar zabeleži poligraf kot psihofiziološki odziv. Teorija je podrobneje predstavljena $\mathrm{v}$ poglavju o tehniki prikritih informacij. Na tem mestu velja zapisati le, da je to eden izmed manj premišljenih poskusov teoretične utemeljitve tehnike primerjalnih vprašanj. $Z$ vidika teorije orientacijskega odziva je uvodni postopek pri tehniki CQT, ko testirani osebi vnaprej predstavimo relevantna vprašanja, videti kot povsem neprimeren. Zaradi vnaprejšnje predstavitve dražljajev pride do nezmožnosti razlikovanja med odzivi na relevantna in primerjalna vprašanja. Odzivi na relevantna vprašanja, če jih interpretiramo kot orientacijski odzivi, se pojavijo zgolj zaradi prepoznave osebno pomembnega dražljaja, ki ga je oseba predhodno videla in ga ima v spominu. Takšen psihofiziološki odziv seveda nima povezave z zavajanjem, ampak s prepoznavo.

Tehnika CQT velja za sporno in je deležna številnih kritik, ki presegajo problem teoretične neutemeljenosti. Tako na primer, Iacono (2000) meni, da obstajajo trije razlogi, zaradi katerih je ta poligrafska metoda sporna: (i) med znanstveniki ni soglasja, da obstaja zadovoljiva teoretična osnova, ki bi upravičila uporabo poligrafa; (ii) poligrafija je ločena od znanosti, uporabljajo jo večinoma poligrafisti, ki se šolajo v zasebnih poligrafskih šolah, ki niso povezane z univerzami; (iii) poligrafski testi imajo daljnosežne in usodne posledice za testirane osebe. Zaradi ločenosti poligrafije od znanosti poligrafisti pri svojem delu ne upoštevajo pomembnih znanstvenih spoznanj (NRC, 2003), ki so predvsem v fiziologiji in psihologiji na voljo že desetletja. Takšna so npr. spoznanja o medosebnem vplivanju (npr. Cialdini, 2001), ki je pomemben vir subjektivnosti pri interpretaciji (merjenju) psiholoških značilnosti posameznikov ali skupin. A nekateri vendarle skušajo integrirati sodobno znanost v teorijo poligrafiranja. Tako npr. Palmatier in Rovner (2015) poskušata utemeljiti veljavnost teorije CQT s teorijo preliminarnih procesov (Barry, 2009). V tem poskusu sta $\mathrm{V}$ teoretični temelj tehnike CQT poskusila vključiti spoznanja sodobne nevroznanosti in psihofiziologije. A ta poskus so argumentirano zavrnili nekateri ugledni znanstveniki (BenShakhar, Gamer, Iacono, Meijer in Verschuere, 2015). Menijo namreč, da gre za neupravičeno in posiljeno utemeljevanje teorije CQT s spoznanji o orientacijskem odzivu.

\section{Standardiziranost in objektivnost poligrafskega testiranja}

Tehnika oziroma test primerjalnih vprašanj velja za nestandardiziran in neobjektiven test. Na rezultate testiranja namreč lahko vplivajo stališča in prepričanja poligrafista o preiskovančevi krivdi, ki temeljijo na predsodkih in nepreverjenih domnevah o preteklosti osumljenca (Elaad, Ginton in Ben-Shakhar, 1994). Poligrafisti imajo na voljo podatke o osumljencu, poleg tega si lahko ustvarijo mnenje o njem med uvodnim intervjujem. Tako se lahko v ugotovitvah poligrafistov odražajo njihova prepričanja ali pričakovanja, kar dokazuje, da test ni tako standardiziran in objektiven, kot menijo njegovi zagovorniki. Videti je, da zagovorniki poligrafa pogosto ne razumejo razlike med znanstveno in neznanstveno metodo. Tako npr. Selič (2009) primerja standardizirane psihološke teste $\mathrm{z}$ nestandardiziranimi poligrafskimi testi in pri tem prezre razliko med znanostjo in psevdoznanostjo, vključno s temeljno težavo poligrafije, ki jo predstavlja odsotnost znanstveno-teoretične utemeljitve metode.

Nezadostna standardiziranost tehnike CQT se kaže $\mathrm{v}$ tem, da so rezultati testiranja odvisni od izkušenosti, usposobljenosti in sposobnosti poligrafista (Lykken, 1998). Zaradi subjektivnosti postopkov poligrafiranja lahko dva poligrafista podata različne ugotovitve. Ujemanje med ugotovitvami različnih ocenjevalcev niha med 61 in $95 \%$ (Caroll, 1988), kar utemeljuje dvome o standardiziranosti in objektivnosti testiranja. Težave s subjektivnostjo testiranja lahko omilimo z uporabo računalniških programov, ki objektivno ovrednotijo fiziološke odzive preiskovancev (Kircher in Raskin, 2002), a razvijalci programske opreme skrivajo podrobnosti statističnih algoritmov. Glede na razpoložljive informacije lahko sklepamo, da napovedovanje 
zavajanja temelji na statističnem modeliranju $\mathrm{z}$ uporabo (logistične) regresijske analize, a podrobnosti postopka niso znane, tako da o objektivnosti ne moremo sklepati.

Zagovorniki tehnike CQT zavračajo kritike o nestandardiziranosti in subjektivnosti, češ da se s kakovostnim in rednim usposabljanjem ter strokovnim nadzorom problem subjektivnosti lahko preseže. A tako razmišljanje je naivno in razkriva nepoznavanje osnovnih psiholoških ugotovitev o medosebnem vplivanju. Raziskave s področja socialne psihologije že desetletja opozarjajo na kompleksnost in razsežnosti medosebnega vplivanja, ki v veliki meri temelji na nezavednih procesih (Cialdini, 2001). Nekateri drugi zagovorniki poligrafiranja se vendarle zavedajo težav (npr. Raskin in Honts, 2002), zato previdno trdijo, da je poligraf le eno izmed orodij, s katerim si preiskovalci pomagajo pri delu. A praksa kaže, da to le redko drži, saj se preiskovalci navadno vedejo, kot da je tehnika edino pravo orodje za ugotavljanje resnice. Poligrafisti so namreč prepričani o visoki zanesljivosti rezultatov testiranja, ki po njihovem sega preko $90 \%$. Tako je za mnoge poligrafiste tehnika edino pravo orodje in ne le eno izmed orodij, ki ga uporabijo za ugotavljanje resnice.

\section{Točnost poligrafskega testa primerjalnih vprašanj}

Kar zadeva točnost ugotavljanja zavajanja s poligrafom, velja, da je precej višja od naključja, a tudi pomembno nižja od popolne zanesljivosti (NRC, 2003). Raziskav o točnosti poligrafskih testiranj je veliko, a za veliko večino velja, da ne dosegajo niti najbolj ohlapnih meril verodostojnosti znanstvenega raziskovanja. Praviloma so to raziskave, ki so jih opravili poligrafisti s podporo poligrafskih organizacij.

Metaštudija 36 raziskav, ki izpolnjujejo najnižja merila znanstvene sprejemljivosti in so bile izvedene na osnovi meritev resničnih osumljencev kaznivih dejanj, kaže, da je s poligrafskimi testi pravilno določenih od 83 do $89 \%$ krivih osumljencev. Deleži krivih osumljencev, ki so napačno spoznani kot nedolžni, se gibljejo od 1 do $17 \%$. Deleži nedolžnih, ki so bili napačno spoznani za krive, segajo od 12 $\%$ do $47 \%$, deleži nedolžnih, ki so bili pravilno ugotovljeni kot nedolžni, pa od 53 do $75 \%$ (Vrij, 2008). Pomembno je omeniti, da so bile $\mathrm{v}$ metaštudijo vključene raziskave tako zagovornikov kot tudi nasprotnikov poligrafiranja. Povzamemo lahko, da znaša povprečna točnost poligrafa pri prepoznavanju krivih osumljencev $86 \%$, povprečen delež nedolžnih, ki so po krivem obtoženi laganja, je $26 \%$, nedolžni pa so pravilno določeni kot nedolžni v $62 \%$ (Vrij, 2008). A pri navajanju točnosti merilnih tehnik je treba upoštevati celotno, splošno točnost in ne samo eno od komponent točnosti, česar se na področju poligrafije praviloma ne spoštuje. Tako se zavajajoče navajajo le visoke točnosti ugotavljanja lažnivcev, brez upoštevanja točnosti ugotavljanja nedolžnih (Lykken, 1998). Ob spoštovanju tega znanstvenega pravila lahko iz predhodno navedenih vrednosti točnosti ugotovimo, da je točnost tehnike primerjalnih vprašanj najverjetneje 74odstotna.

Raziskave, ki so bile opravljene z analizo meritev resničnih preiskovalnih primerov, imajo visoko zunanjo veljavnost, a pomembno slabost. Izhodiščna resnica namreč ni znana, kar pomeni, da ne moremo zanesljivo vedeti, ali je bila testirana oseba kriva ali nedolžna. Če so na voljo zanesljivi materialni dokazi, potem je izhodiščna resnica dokaj zanesljiva, a v takih primerih se poligrafiranje ne uporabi (Honts, Kircher in Raskin, 2002). Izhodiščno resnico lahko poskusimo določiti tudi s pomočjo priznanj storilcev kaznivih dejanj, kar pa je slaba rešitev. Zaradi nje pride do pristranskosti vzorčenja meritev, kar vodi v napihovanje točnosti (glej Patrick in Iacono, 1991a, b).

Točnost poligrafa, ki je bila ugotovljena v nadzorovanem laboratorijskem okolju, je podobna kot pri prej omenjenih terenskih študijah, kar je ugotovil Vrij (2008) v primerjavi 65 metodološko zadovoljivih študij o točnosti poligrafa. Podobno kot prej lahko ugotovimo, da povprečna točnost poligrafa $\mathrm{v}$ laboratorijskih raziskavah znaša $76 \%$.

\section{Test prikritih informacij (CIT)}

Test prikritih informacij je bil v preteklosti bolj poznan kot test védenja krivcev (Guilty Knowledge Test - GKT; Lykken, 1959), vendar se danes uporablja primernejša oznaka, torej test prikritih informacij. Uporabljajo ga predvsem na Japonskem in v Izraelu. V preiskovalni in sodni praksi ga redno uporabljajo le Japonci, ki so pred približno 15 leti opustili uporabo spornih testov CQT (Osugi, 2011). Tehnika CIT je namreč znanstveno in etično bolj ustrezna ali primerna kot tehnika CQT (Krapohl, McCloughan in Senter, 2009), zato je njena uporaba manj sporna.

Test prikritih informacij se uporablja pri ugotavljanju, ali osumljenec prepozna informacije, povezane s kaznivim dejanjem, ki jih sicer nedolžna oseba ne bi prepoznala (Lykken, 1998). Med testom preiskovalec predstavi testirancu več dražljajev, kot so fotografije, odgovori na vprašanja ali skice. V setu izzivov ali dražljajev je le eden povezan $\mathrm{s}$ kaznivim dejanjem. Dražljaji so izbrani tako, da nedolžne osebe ne zaznajo razlike med relevantnimi in irelevantnimi dražljaji, kar pomeni, da se na vse dražljaje odzovejo približno enako. Vsak dražljaj je predstavljen le enkrat v seriji, ki pa je lahko predstavljena večkrat, a z drugačnim zaporedjem predstavljanja dražljajev. Med testiranjem se merijo fiziološki odzivi na dražljaje. Če v odzivih testiranca ni razlik med relevantnimi in irelevantnimi dražljaji, osumljenec najverjetneje ni prepoznal relevantnih dražljajev, ki so povezani z zločinom. Če pa se pojavi razlika v odzivih, potem je osumljeni dokaj verjetno prepoznal ključne dražljaje. To lahko pomeni, da imamo opravek z osebo, ki pozna podrobnosti kaznivega dejanja. Če informacije o zločinu niso znane javnosti ali osumljencem, potem je verjetnost, da bo nedolžna oseba prepoznana kot obveščena, odvisna od števila testnih vprašanj in odgovorov (dražljajev). Več ko je testnih vprašanj in možnih odgovorov, manjša je možnost napake.

Najbolj prepričljiv znanstveno-teoretični temelj tehnike prikritih informacij predstavlja teorija o orientacijskem refleksu ali odzivu, ki se pojavi, ko oseba zazna zanjo pomemben dražljaj (Pavlov, 1927/2003). Dražljaj v obliki fotografije znanega predmeta ima signalno vrednost, zaradi česar se bo najverjetneje pojavil orientacijski odziv, ki bo večji kot pri drugih dražljajih brez signalne vrednosti (Lykken, 1998). Pri orientacijskem odzivu se pojavijo fiziološki 
odzivi, ki se jih lahko meri s poligrafom. Tako npr. pride do povečanja elektrodermalne aktivnosti in upočasnitve srčnega utripa (Nakayama, 2002). Če je nekdo moril z nožem, ki ga je nato pustil na kraju zločina, se bo pri njem najverjetneje pojavil orientacijski odziv, ko bo zagledal sliko uporabljenega orožja. Poligrafist namreč pokaže več slik podobnih nožev, med katerimi je tudi pravi. Pri tem lahko osumljenca za vsak nož vpraša, ali je bil uporabljen pri kaznivem dejanju. Še pred tem osumljenec dobi navodila, naj na vsa vprašanja odgovori z »Ne«. Ker morilec pozna morilsko orožje, se pri sliki pravega noža najverjetneje pojavi orientacijski odziv. Nedolžni osumljenci ne vedo, kateri nož je bil uporabljen pri zločinu, zato se pri njih orientacijski refleks ne pojavi. Pomembno je, da je pri vprašanjih na testu CIT na voljo več odgovorov. Navadno se zastavi pet ali šest vprašanj, pri vsakem so na voljo vsaj štirje napačni in en pravilen odgovor (Osugi, 2011). Če uporabimo pet vprašanj s petimi odgovori, je verjetnost, da bi se orientacijski refleks naključno pojavil pri vsakem od petih vprašanj, ena proti 3.125. Priporočljivo je, da poligrafist ni seznanjen s pravilnimi odgovori, sicer se lahko pri opazovanju odzivov testiranca vedenje poligrafista spremeni, kar vpliva na testiranca in na ugotovitve testiranja (Osugi, 2011).

Prvotne raziskave na področju tehnike prikritih informacij so bile osredotočene na merjenje sprememb v električni prevodnosti kože, danes pa se več pozornosti posveča analizi možganskih evociranih potencialov in slikanju delovanja možganov (Rosenfeld idr., 2012). Gre torej za odkrivanje prikritih informacij s tehnikami, ki temeljijo na merjenju sprememb možganskega valovanja in ravni kisika $\mathrm{v}$ krvi možganskega tkiva. Pri merjenju možganskega valovanja analiziramo spremembe možganskih potencialov, povezanih z dogodki (angl. event related potential ali ERP), ki se manifestirajo v osrednjem živčevju. Te spremembe beležimo $\mathrm{z}$ elektroencefalografijo (EEG), med njimi pa je $\mathrm{z}$ vidika ugotavljanja zavajanja najbolj uporabno elektromagnetno valovanje s tehnično oznako P300. To valovanje se pojavi le pri odzivih na osebno pomembne dražljaje in ga lahko pojasnimo kot orientacijski odziv. Oznaka valovanja izhaja iz njegovih lastnosti, saj amplituda valovanja doseže največjo vrednost 300 do $800 \mathrm{~ms}$ po zaznavi pomembnega dražljaja (Meijer, Selle, Elber in Ben-Shakhar, 2014). Pri tehniki EEG-P300 preiskovancu navadno na zaslonu prikazujemo vprašanja in možne odgovore ter snemamo možgansko valovanje. Ko preizkušanec zazna pomemben dražljaj, se pojavi odziv, ki je viden iz posnetih krivulj možganskega valovanja.

Tehnika EEG-P300 ima slabosti, ki preprečujejo njeno razširitev. V primerjavi $\mathrm{z}$ navadnimi poligrafskimi testi prikritih informacij so preiskave EEG neudobne. Razlog za to je predvsem v tem, da je za pridobitev zanesljivih rezultatov treba do 30-krat ponoviti meritve (Rosenfeld, Shue in Singer, 2007). EEG naprave so tudi neprimerljivo dražje in zahtevajo večji namestitveni prostor kot konvencionalna poligrafska oprema. Prevladuje mnenje, da tehnika EEG-P300 ne more bistveno preseči točnosti klasičnega poligrafiranja in najverjetneje je točnost tehnike $\mathrm{v}$ nelaboratorijskem okolju celo nekoliko nižja (Meijer idr., 2014).

Med novejše poskuse odkrivanja laži $z$ meritvami možganskega valovanja sodi tudi tehnika MERMER (angl. memory and encoding related multifaceted electroencephalographic response; nekateri tehniko označujejo tudi kot $\mathrm{P} 300+$ ), ki je podobna tehniki EEGP300. Pri njej ne snemajo le valovanja P300, ampak več vrst možganskega valovanja. Avtor Lawrence Farwell tehniko imenuje tehnika možganskih odtisov (angl. brain fingerprinting) in trdi, da je stoodstotno točna pri ugotavljanju laži (Farwell, 2012; Farwell in Smith, 2001). A to je že s teoretičnega vidika nemogoče, saj se tehnika MERMER sooča $\mathrm{z}$ enakimi težavami kot tehnika ugotavljanja prikritih informacij (CIT). Tehnika velja za nepreverjeno in temelji na dvomljivih raziskovalnih ugotovitvah (Senior, Haggard in Oates, 2011). Poleg tega avtor tehnike utemeljuje njeno veljavnost zzavajajočimi in napačnimi podatki ter pretiravanji, ki preverjeno ne držijo (Vrij, 2008).

Zavajanje lahko ugotavljamo tudi s tehniko snemanja delovanja možganov $\mathrm{s}$ funkcijsko magnetno resonanco (angl. functional magnetic resonance imaging ali fMRI), ki omogoča tridimenzionalen vpogled $\mathrm{v}$ delovanje možganov (White, 2010). Vendar pa tudi ta tehnika sproža številne pomisleke. Ena ključnih težav je, da je večina raziskav opravljena $\mathrm{v}$ laboratorijih in na način, ki ni podoben resničnim življenjskim okoliščinam. Zato je točnost tehnike, ki naj bi znašala približno $90 \%$, najverjetneje precenjena (Weisberg, Keil, Goodstein, Rawson in Gray, 2008). Tehnika je tudi dokaj občutljiva na uporabo protiukrepov, s katerimi testiranec prikrije svoje odzive (Ganis, Rosenfeld, Meixner, Kievit in Schendan, 2011) in velja za neraziskano (Rachul in Zarzeczny, 2012).

\section{Presoja testa prikritih informacij}

\section{Teoretična utemeljenost tehnike}

Teorija o orientacijskem refleksu ali odzivu (Pavlov, 1927/2003) je najbolj prepričljiv teoretični temelj tehnike prikritih informacij, ki ga je prvi uporabil Lykken ob koncu 50. let (Lykken, 1959). Orientacijski odziv je izraz, s katerim označujemo skupek odzivov, ki jih izzove nov dražljaj ali sprememba stimulacije (Sokolov, 1963). Vsaka vhodna informacija je primerjana $\mathrm{z}$ obstoječimi nevronskimi modeli ali notranjimi reprezentacijami. Če pride do neskladja med vhodnimi informacijami in nevronskimi modeli, se pojavi orientacijski odziv. Če razlike ni, je odziv inhibiran in pojavi se habituacija. Orientacijski odziv se pojavi tudi pri zaznavi osebno pomembnih dražljajev, ki so zaradi svoje pomembnosti odporni na habituacijo ali ugašanje intenzitete (Sokolov, 1963), kar je še bolj očitno, ko ima dražljaj čustveni naboj (Bradley, 2009). Pri krivi (obveščeni) osebi ima relevanten dražljaj poseben pomen ali dodano signalno vrednost, ki najverjetneje sproži intenzivnejši orientacijski odziv kot drugi, irelevantni dražljaji. Za nedolžne osebe relevantni dražljaji niso osebno pomembni, zato sprožijo podobno intenzivne fiziološke odzive kot irelevantni dražljaji in ugašajo s ponovitvami predstavljanja istih dražljajev (Lykken, 1998).

Teorija orientacijskega odziva zanemarja vpliv motivacije in čustev na pojavljanje odzivov, saj omenjeni dejavniki niso omenjeni kot vplivni. Zaradi tega je s teorijo težko pojasniti, zakaj namerno izogibanje razkritju zavajanja prispeva $\mathrm{k}$ diferenciaciji med relevantnimi in irelevantnimi 
(nevtralnimi) dražljaji, kot je to bilo ugotovljeno v nekaterih študijah (npr. Furedy in Ben-Shakhar, 1991). Videti je, kot da motivacija vendarle vpliva na intenziteto orientacijskega odziva, saj je verjetno povezana s pomenom, ki ga ima dražljaj za posameznika. Čim bolj je (relevanten) dražljaj osebno pomemben za zavajajočo osebo, bolj je ta motivirana za prikritje odziva, a ob prizadevanju za prikritje pomembnega dražljaja se pojavi intenzivnejši orientacijski odziv.

Kljub vsemu teorija orientacijskega odziva lahko pojasni večino raziskovalnih ugotovitev, povezanih s testom CIT, a takšna teoretična utemeljitev ima še več šibkih točk. Če je osebni pomen dražljaja videti kot uporaben koncept, se lahko vprašamo tudi, kako ga natančneje opredeliti. Osebna pomembnost je nejasna opredelitev, ki pušča veliko svobode različnim interpretacijam pomena relevantnih in nevtralnih dražljajev. Kako lahko v ta koncept vpnemo čustveni naboj in motivacijo? Kako lahko zanesljivo sklepamo, da je nek relevanten dražljaj zares pomemben za neko osebo in nevtralen dražljaj zares nepomemben? Poleg tega je teoretični temelj testa CIT slabo raziskan v resničnih življenjskih okoliščinah. Raziskave z visoko zunanjo (ekološko) veljavnostjo so redke, zato ne vemo zanesljivo, kako je z diferenciacijo odzivov med relevantnimi in nevtralnimi dražljaji v okoliščinah visokega tveganja za testirano osebo (npr. razkritje prikrivanja informacij ima lahko resne posledice za posameznika).

\section{Točnost testa prikritih informacij}

Metaštudija, v katero je bilo zajetih 56 laboratorijskih raziskav, ki zadoščajo minimalnim standardom znanstvenega raziskovanja, kaže, da so krivi testiranci pravilno prepoznani kot krivi v razponu od 76 do $88 \%$. A pri tem je tudi od 12 do $24 \%$ krivih preiskovancev napačno opredeljenih kot nedolžnih (Vrij, 2008). Za razliko od tehnike primerjalnih vprašanj je test prikritih informacij natančnejši pri določanju nedolžnih preiskovancev, saj so neobveščeni prepoznani kot neobveščeni (nedolžni) v 94-99 \%, nedolžni pa so kot krivi prepoznani v 1-6 \% (Vrij, 2008). Tako obstaja majhna verjetnost, da je nedolžna ali neinformirana oseba napačno spoznana za vpleteno v predmet preiskave. Podobne vrednosti točnosti tehnike CIT so ugotovili tudi drugi (npr. Meijer idr., 2014). Raziskave $\mathrm{z}$ višjo zunanjo veljavnostjo, kjer so testiranci bolj motivirani za prikrivanje informacij in so okoliščine bolj podobne resničnim preiskovalnim okoliščinam, kažejo višjo točnost. Tako so pri določanju krivih ugotovili 92-odstotno točnost, pri določanju nedolžnih pa 90-odstotno točnost (Elaad, 2013). Rezultatov terenskih študij, torej raziskav z vključitvijo resničnih preiskovalnih primerov, še ne moremo posploševati, ker jih je premalo in/ali so metodološko prešibke.

Če povzamemo, povprečna točnost ugotavljanja krivih testirancev znaša $82 \%$, točnost ugotavljanja nedolžnih pa $94 \%$, a pri tem obstaja velik delež krivih osumljencev, ki jih napačno prepoznamo kot nedolžne, in ta znaša $18 \%$ (Vrij, 2008). Tako kot pri tehniki primerjalnih vprašanj lahko tudi pri tehniki prikritih informacij izračunamo njeno splošno točnost, in ta je najverjetneje $88 \%$. Videti je, da je tehnika CIT bolj točna kot tehnika CQT, a ima kar nekaj omejitev v praktični uporabi.

\section{Uporabnost tehnike CIT}

Test prikritih informacij je včasih težko uporabiti $\mathrm{v}$ preiskovalni praksi. Testa npr. ne moremo uporabiti, če osumljenec prizna vpletenost $\mathrm{v}$ zločin. $\mathrm{V}$ tem primeru pozna nekatere podrobnosti zločina, ni pa nujno storilec. Podobne težave nastanejo tudi, če več osumljencev prizna vpletenost v zločin, vendar nihče ne prizna, da je dal pobudo zanj. Poleg tega lahko preiskovalec oblikuje testna vprašanja le, če pozna nekaj dejstev o zločinu. A pri preiskavah je pogosto znanih premalo podrobnosti, da bi izoblikovali metodološko ustrezen test. Tako je Podlesny (1993) preučil zločine, ki jih je preiskoval ameriški Zvezni preiskovalni urad (FBI), in ugotovil, da bi lahko test prikritih informacij uporabili le v 13 $\%$ preiskav. A zavedati se moramo, da bi test lahko uporabljali pogosteje, če bi bili preiskovalci usposobljeni za iskanje za test primernih podrobnosti na kraju zločina. Tudi kadar uporabnih informacij nimamo, lahko izvedemo test iskanja vrhunca napetosti (SPOT), kjer je postopek enak kot pri testu prikritih informacij. Če se pri osumljencu pojavi izrazit fiziološki odziv na enega od dražljajev, lahko preiskovalci na tej podlagi iščejo nove dokaze.

Znanstveno-teoretično izhodišče testa prikritih informacij je delno sprejeto in ni tako vprašljivo, kot je pri testu primerjalnih vprašanj (Ben-Shakhar, Verschuere in Meijer, 2011; Saxe, 1991). Kljub temu se pojavljajo upravičeni pomisleki glede uporabe testa. Če je bil npr. pri kaznivem dejanju uporabljen revolver, osumljeni pa ima takšno orožje doma, se lahko ob ogledu fotografije podobnega orožja pojavi orientacijski odziv. To pomeni, da je preiskovanec zaznal osebno pomemben dražljaj, in ne, da je vpleten $\mathrm{v}$ zločin. Nemogoče je tudi zanesljivo ugotoviti, katere stvari s kraja zločina si je storilec zapomnil in jih zato prepozna $\mathrm{v}$ testu (Honts, 2004). Storilec lahko tudi pozabi podrobnosti, zato je treba test prikritih informacij izvesti čim prej, najkasneje dva tedna po preiskovanem dogodku (Peth, Vossel in Gamer, 2012). Težavo pri uporabi testa prikritih informacij predstavlja tudi testiranje storilcev serijskih zločinov. Če nekdo vlomi v deset stanovanj na podoben način, se težko spomni podrobnosti iz točno določenega vloma. Serijske prestopnike je zato treba soočati s podrobnostmi, ki so edinstvene za preiskovano kaznivo dejanje.

Pogosto je v praksi tudi težko izbrati ustrezne relevantne in irelevantne (kontrolne) dražljaje. Če so irelevantni odgovori ali dražljaji pomensko preblizu relevantnim, najverjetneje ne bomo ugotovili razlik pri analizi fizioloških odzivov (BenShakhar, Gati in Salamon, 1995). Tako prikrivanja podatkov ne moremo ugotoviti. Obstaja tudi verjetnost, da odgovori (dražljaji) izzovejo psihofiziološke odzive zaradi narave vprašanj. Izrazit odziv se pri določenem odgovoru lahko pojavi samo zato, ker se zdi preiskovancu verjetnejši kot drug odgovor. Takšne težave lahko zmanjšamo s preverjanjem odzivov na odgovore pri potrjeno nedolžnih osebah, kar moramo opraviti pred testiranjem osumljenca. V ta namen lahko uporabimo Doob-Kirshenbaumov postopek (Doob in Kirshenbaum, 1973), v katerem več oseb presoja o morebitnem izstopanju specifičnega dražljaja v množici drugih podobnih dražljajev. Pri nedolžnih osebah morajo biti odzivi na vse dražljaje približno enaki, sicer moramo izločiti tiste dražljaje, 
ki so bili izbrani redkeje ali pogosteje kot drugi, in izbrati primernejše.

Pomembna in tudi pogosta težava testa prikritih informacij je seznanjenost testirane osebe s podrobnostmi zločina. Do tega lahko pride zaradi poročanja medijev, pogovora $\mathrm{z}$ drugimi osebami ali pa zaradi intervjujev, ki jih preiskovalci opravijo z osumljeni. Med pogovori lahko kriminalisti omenijo podrobnosti, ki jih zato ne moremo uporabiti pri kasnejšem testiranju. To je pogosta težava tam, kjer policisti uporabljajo prisilne (obtožilne) tehnike zaslišanj, da bi od osumljenih izvabili obremenilne izjave (Hartwig, Granhag, Strömwall in Kronkvist, 2006).

\section{Razprava}

Včlankusokritičnopredstavljenepomembnejšeugotovitve o dveh najbolj uveljavljenih tehnikah psihofiziološkega ugotavljanja zavajanja; testa primerjalnih vprašanj (CQT) in testa prikritih informacij (CIT). Med njima so pomembne razlike $\mathrm{v}$ teoretični utemeljenosti, $\mathrm{v}$ izpolnjevanju kriterijev znanstvene in etične sprejemljivosti ter $\mathrm{v}$ načinih uporabe. Razlike kažejo, da je test prikritih informacij znanstveno sprejemljivejši in na splošno manj sporen kot test primerjalnih vprašanj. Morda najpomembnejši razliki med testoma sta $\mathrm{v}$ tem, (i) da pri testu CIT ne ugotavljamo zavajanja, ampak odkrivamo obstoj prikritih podatkov $\mathrm{v}$ spominu testirane osebe, in (ii) da pri testu CIT ne zavajamo testiranih oseb. A tudi pri takšni uporabi poligrafa naletimo na resne težave in dileme, ki postavljajo pod vprašaj uporabo poligrafa.

Glede točnosti poligrafskih meritev je treba poudariti, da se giblje od približno $76 \%$ pri tehniki CQT do $88 \%$ pri tehniki CIT, kar je opazno manj, kot trdijo zagovorniki uporabe poligrafa. Višjo točnost je pravzaprav težko pričakovati, saj je odvisna od vrste spremenljivk, ki jih je težko ali pa celo nemogoče nadzorovati. Tako se npr. fiziološki odzivi testiranih oseb razlikujejo med posamezniki (npr. Kosslyn idr., 2002), opazen vpliv ima tudi družbeni kontekst, v katerem se izvaja testiranje (npr. Blascovich, Mendes, Hunter, Lickel in KowaiBell, 2001). To sta spremenljivki, ki ju je težko nadzorovati, ker je njun vpliv prikrit med poligrafskim testiranjem. Tako je razumljivo, da dejanska točnost poligrafa niti teoretično ne more doseči točnosti, ki jo navajajo zagovorniki.

Glavna kritika teorije testa CQT je v tem, da je zanikanje napačnih obtožb čustveno dokaj vznemirjujoče za nedolžno osebo. To velja še toliko bolj, če se nedolžni zaveda resnosti posledic padca na poligrafskem testu. Te so lahko povezane $\mathrm{Z}$ občutki ponižanja, izgube ugleda ali osamitve $\mathrm{v}$ širšem in ožjem socialnem okolju posameznika. Poleg tega posameznik tvega tudi, da bo izpostavljen neupravičenemu kazenskemu pregonu in morda celo zmotni obsodbi. Zaradi stresnosti oz. vpliva čustvenega vznemirjenja ne moremo zanesljivo vedeti, od kod izvira razlika med odzivi na relevantna in primerjalna vprašanja. Test CQT je zato pristranski v škodo nedolžnih oseb in nekatere (terenske) raziskave to potrjujejo. Patrick in Iacono (1991a) sta pri izkušenih policijskih poligrafskih preiskovalcih ugotovila kar $40 \%$ zmotno pozitivnih odločitev pri nedolžnih osumljencih. Delež zmotno pozitivnih odločitev je pri testu CIT bistveno manjši, vendar je zato delež zmotno negativnih odločitev višji. Zato test le malo ogroža nedolžne, a pomeni večje tveganje za zmotno izpuščanje storilcev iz kroga osumljencev.

Večina poligrafskih raziskav s tehniko CQT je brez ali s pomanjkljivo teoretično utemeljitvijo. V glavnem so raziskave usmerjene $\mathrm{v}$ prizadevanja po dvigu točnosti poligrafskih meritev oz. odločitev, kar skušajo doseči s spreminjanjem ali dopolnjevanjem načina testiranj in obdelave pridobljenih podatkov. Le izjemoma avtorji razmišljajo o psiholoških mehanizmih in procesih, ki ležijo $v$ ozadju odzivov. To je po eni strani presenetljivo, saj ti procesi pomembno vplivajo na točnost poligrafa pri ugotavljanju zavajanja ali iskrenosti, po drugi strani pa je razumljivo, ker je te procese težko raziskovati. Zaradi takšne raziskovalne omejenosti ne vemo skoraj nič o tem, kako je doživljanje čustev povezano z zavajanjem, kakšne so intraindividualne razlike v odzivanju in kakšne so razlike med posamezniki v ugotavljanju zavajanja. Malo tudi vemo o vplivu pričakovanj in stigme na ugotavljanje zavajanja. Treba je tudi opozoriti, da so raziskave na populacijah, katerih pripadniki so pogosto testirani, redke in ne ponujajo zadovoljivih odgovorov. Gre za populacije, ki jih npr. predstavljajo kandidati za zaposlitve, teroristi in različne vrste storilcev kaznivih dejanj. Med zadnjimi je vredno opozoriti na osebe $\mathrm{z}$ antisocialno motnjo osebnosti oz. psihopate, ki zavzemajo opazen delež med osumljenci policijskih preiskav. Če so psihopati čustveno neodzivni in hladnokrvni manipulatorji, je uporaba poligrafa pri njih sploh smiselna?

Ena izmed resnih težav poligrafiranja je tudi uporaba protiukrepov, s katerimi preiskovanci zavajajo poligrafiste. Preiskovanci skušajo nadzorovati fiziološke odzive in tako prepričati poligrafista, da so iskreni. Protiukrepe delimo $\mathrm{v}$ telesne in duševne, zadnji veljajo za resnejše, ker jih je nemogoče odkriti (Honts, 1987). Med pogoste duševne protiukrepe sodi npr. tiho štetje od 100 navzdol v koraku po nekaj številk, med telesnimi protiukrepi pa se najpogosteje povzroča bolečino samemu sebi, kot npr. prikrito zbadanje z nohti. Večina zagovornikov poligrafiranja meni, da izkušeni poligrafisti vedno ugotovijo poskuse prevar (npr. Reid in Inbau, 1977), a protiukrepe je mogoče uspešno uporabiti, če se jih prej naučimo (Honts in Alloway, 2007). Ker so navodila za učenje protiukrepov prosto dostopna $\mathrm{v}$ svetovnem spletu (npr. AntiPolygraph.org), je naivno pričakovati, da testirane osebe ne morejo pretentati poligrafista.

Vrednojeomenititudinekatereetičneinpravnedileme.Prva je uporaba zavajanja, ki je nujna sestavina testa primerjalnih vprašanj (CQT) in se uporabi večkrat. Pred testiranjem skuša poligrafist prepričati osumljenca o nezmotljivosti poligrafa, kar je zavajajoče. Nujno je tudi prepričati testiranca, da intenzivni odzivi na kontrolna vprašanja dokazujejo, da laže, kar ne drži. Če se oseba močneje odzove na kontrolna kot na relevantna vprašanja, poligrafist sklepa, da preiskovanec govori resnico. Zavajajoč je tudi uvodni stimulacijski test, s katerim se skuša dokazati nezmotljivost poligrafa s pomočjo igralnih kart. Stimulacijski test je namreč test prikritih informacij, ki se ga kasneje med testiranjem ne uporabi, ker se uporabi test primerjalnih vprašanj. Tako se popolnost poligrafa predstavi $\mathrm{z}$ načinom, ki potem ni uporabljen. Osumljenec je tako že pred začetkom testiranja trikrat prevaran. Prevare so nujne, ker je test lahko nezanesljiv, če testirana oseba dvomi o popolni točnosti poligrafa. Iluzijo 
nezmotljivosti poligrafa pa je težko doseči, ker ima večina ljudi izkušnje $\mathrm{z}$ napakami v delovanju elektronske opreme, mediji pa pogosto poročajo o usodnih napačnih odločitvah vrhunskih strokovnjakov. Uporaba poligrafiranja je vprašljiva tudi s pravnega vidika, saj lahko testiranje razumemo kot neprostovoljno izdajanje informacij mimo ali zoper svojo voljo (Flander, 2004). To pomeni, da so pri uporabi poligrafa lahko kršene temeljne pravice preiskovancev. Uporaba testa s primerjalnimi vprašanji (CQT) je zato v nekaterih državah, predvsem v evropski skupnosti, označena kot protizakonita.

Mnogi tudi menijo, da je uporaba tehnike primerjalnih vprašanj nedopustna zaradi visokega tveganja za pojav lažno pozitivnih rezultatov, kar pomeni, da je osumljeni napačno spoznan za krivega. Napačna obtožba poligrafista ne pomeni nujno napačne obsodbe, a lahko ima daljnosežne posledice, kot je na primer večje število zaslišanj, agresivnejša zaslišanja, daljše bivanje $\mathrm{v}$ priporu, pridobitev socialne etikete zločinca in težave $\mathrm{v}$ odnosih $\mathrm{z}$ bližnjimi. V okoljih, kjer se uporabljajo prisilne zasliševalske tehnike, s katerimi osumljence spodbujamo k priznanju, je uporaba poligrafske tehnike primerjalnih vprašanj dejavnik povečanega tveganja za pojav izsiljenih priznanj (Kassin, 2008).

Neetičnost in neznanstvenost poligrafiranja je tudi razlog za to, da je poligrafsko preverjanje zaposlenih in kandidatov za zaposlitve neprimerno in odsvetovano (npr. BPS, 2004). Gre namreč za to, da se tehnika, ki je bila razvita za zaslišanja osumljencev zločinov, prenaša $v$ drugačen kontekst uporabe, ki je znanstveno nepreverjen. Zaradi tega so rezultati testiranj manj zanesljivi kot pri testiranju osumljencev, organizacije pa se izpostavljajo večjim varnostnim tveganjem, kot bi se, če bi se držale klasičnih varnostnih procedur.

Poligrafski test prikritih informacij (CIT) ima bolj trdno znanstveno-teoretično osnovo kot test primerjalnih vprašanj, zato $\mathrm{z}$ njim bolj veljavno ugotavljamo iskrenost testiranih oseb. A test prikritih informacij vseeno ne more imeti dokazne vrednosti. Delež napak pri določanju lažnivcev je namreč previsok. Če bi se sodišča odločala na osnovi poligrafskih izvidov, bi se roki pravice izmuznilo preveč storilcev kaznivih dejanj. Temu navkljub je test prikritih informacij primernejši za uporabo pri preiskovanju kaznivih dejanj kot test primerjalnih vprašanj, saj je pri njegovi uporabi manjša verjetnost, da je nedolžna oseba spoznana kot kriva.

Pri razmišljanju o uporabi poligrafa se postavlja tudi vprašanje, ali je poligrafiranje osumljencev sploh potrebno. Uporablja se predvsem tam, kjer pri preiskovanju kaznivih dejanj uporabljajo obtožilne zasliševalske tehnike, s katerimi skušajo zasliševalci pridobiti obremenilne izjave ali priznanja. Vsaj deloma to velja tudi za razgovore z osumljenci v Sloveniji (Areh, Zgaga in Flander, 2016; Areh, Walsh in Bull, 2015). Poligrafiranje se tako uporablja kot prisilna zasliševalska tehnika, ki ima učinek zastraševanja. Da bi zagotovili primerno raven varovanja pravic osumljencev in učinkovitost preiskovanja,je bolje, da zaslišanja spremenimo v preiskovalne intervjuje, ki temeljijo na vzpostavljanju spoštljivega odnosa (raporta) $\mathrm{z}$ intervjuvanci, kot so to naredili $\mathrm{v}$ razvitejših državah. Ne smemo pozabiti, da je med osumljenci veliko povratnikov, ki zaradi preteklih slabih izkušenj z zaslišanji ne želijo sodelovati s preiskovalci in čutijo odpor do policije in pravosodja. Raziskave potrjujejo, da če želimo priti do operativno uporabnih podatkov in spoznanja resnice, potem je priporočljivo vzpostaviti spoštljiv in razumevajoč odnos z osumljenci (Kebbell, Alison in Hurren, 2008). Gre torej za odnos, ki ne vključuje psihične manipulacije, kot je uporaba poligrafa.

Danes je razvitih kar nekaj tehnik, ki omogočajo zadovoljivo točnost ugotavljanja laži brez poligrafa. Takšne so npr. kriterijska vsebinska analiza (angl. criteria based content analysis ali CBCA; Köhnken, 2004), tehnika premišljenega soočanja $\mathrm{z}$ dokazi (angl. strategic use of evidence ali SUE; Granhag, Stromwall in Hartwig, 2007) in tehnika induciranja kognitivne obremenitve (Walczyk, Igou, Dixon in Tcholakain, 2013). Na voljo je torej več orodij za ugotavljanje zavajanja, ki so toliko preizkušena, da jih lahko uporabljamo v preiskovanju. Kljub temu se v pravosodju, policiji in drugih varnostnih organizacijah pojavljata odpor do uporabe znanstvenih ugotovitev in oklepanje zdravorazumskih prepričanj o ugotavljanju laganja (Masip, Herrero, Garrido in Barba, 2011). To je razlog za skrb, saj je oklepanje subjektivnih domnev povezano $\mathrm{z}$ visokim tveganjem za sprejemanje napačnih odločitev $\mathrm{z}$ resnimi posledicami. Zaradi oklepanja psevdoznanstvenih spoznanj ostajamo osredotočeni na iskanje krivca in ne resnice, kar je lagodneje in pomaga vzdrževati iluzijo pravičnega sveta. Oklepanje zdravorazumskih bližnjic je verjetno povezano tudi $\mathrm{z}$ distanciranostjo, zavračanjem in včasih tudi $\mathrm{s}$ kritizerstvom, ki je, v zvezi s poligrafijo, med psihologi pogosto (Vrij, 2008). To verjetno izhaja iz nepremišljenega tolmačenja nekaterih postavk psihološkega etičnega kodeksa. Ta npr. psihologom prepoveduje zagovarjanje in promoviranje ocenjevalnih tehnik, ki jih izvajajo psihološko nekvalificirane osebe (American Psychological Association [APA], 2010). Togo upoštevanje tega določila lahko vodi $\mathrm{v}$ odvračanje znanstvenikov od preučevanja takšnih ocenjevalnih tehnik. Tako ostajajo raziskovalno nepreverjene, in kar je morda še huje - obračanje vstran omogoča, da se psevdoznanstvene tehnike razširjajo in utrjujejo iluzijo znanstvenosti.

\section{Literatura}

American Psychological Association (2010). Ethical principles of psychologists and code of conduct. Pridobljeno s strani: https://www.apa.org/ethics/code/principles.pdf

Areh, I. (2011). Forenzična psihologija: Predstavitev, pričanje in ugotavljanje laži [Forensic psychology: Presentation, testimony and lie detection]. Ljubljana, Slovenija: Univerza v Mariboru.

Areh, I., Walsh, D. in Bull, R. (2015). Police interrogation practice in Slovenia. Psychology, Crime \& Law, 21, $1-15$.

Areh, I., Zgaga, S. in Flander, B. (2016). Police interrogation of suspects in Slovenia. V D. Walsh, G. E. Oxburgh, A. D. Redlich in T. Myklebust (ur.), International developments and practices in investigative interviewing and interrogation (str. 204-214). London, Združeno kraljestvo: Routledge.

Barry, R. J. (2009). Habituation of the orienting reflex and the development of Preliminary Process Theory. Neurobiology of Learning and Memory, 92, 235-242. 
Bashore, T. R. in Rapp, P. E. (1993). Are there alternatives to traditional polygraph procedures? Psychological Bulletin, 113, 3-22.

Ben-Shakhar, G. (2012). Current research and potential applications of the Concealed Information Test: An overview. Frontiers in Psychology, 3(342).

Ben-Shakhar, G., Gamer, M., Iacono, W., Meijer, E. in Verschuere, B. (2015). Preliminary Process Theory does not validate the Comparison Question Test: A comment on Palmatier and Rovner (2015). International Journal of Psychophysiology, 95(1), 16-19.

Ben-Shakhar, G., Gati, I. in Salamon N. (1995). Generalization of the orienting response to significant stimuli: The roles of common and distinctive stimulus component. Psychophysiology, 32, 36-42.

Ben-Shakhar, G., Verschuere, B. in Meijer, E. (2011). Epilogue: Current status and future develpments in CIT research and practice. V B. Verschuere, G. Ben-Shakhar in E. Meijer (ur.), Memory detection: Theory and application of the Concealed Information Test (str. 303-309). Cambridge, Združeno kraljestvo: Cambridge University Press.

Blascovich, J., Mendes, W. B., Hunter, S. B., Lickel, B. in Kowai-Bell, N. (2001). Perceiver threat in social interactions with stigmatized others. Journal of Personality and Social Psychology, 80, 253-267.

Bradley, M. M. (2009). Natural selective attention: Orienting and emotion. Psychophysiology, 46(1), 1-11.

British Psychological Society (2004). A review of the current scientific status and fields of application of polygraphic deception detection: Final report from the BPS Working Party. Pridobljeno s strani: http://www.bps.org.uk

Bull, R. (1988). What is the lie-detection test? V A. Gale (ur.), The polygraph test: Lies, truth and science (str. 10-19). London, Združeno kraljestvo: Sage.

Canter, D. in Žukauskiene, R. (2008). Psychology and law: Bridging the gap (psychology, crime and law). Abingdin, Združeno kraljestvo: Routledge.

Carroll, D. (1988). How accurate is polygraph lie detection? V A. Gale (ur.), The polygraph test: Lies, truth and science (str. 20-28). London, Združeno kraljestvo: Sage.

Cialdini B. R. (2001). Influence: Science and practice (4. izd.). Needham Heights, MA, ZDA: Allyn and Bacon.

Davis, R. C. (1961). Physiological responses as a means of evaluating information. V A. Biderman in H. Zimmer (ur.), Manipulation of human behavior (str. 142-168). New York, NY, ZDA: Wiley.

Doob, A. N. in Kirshenbaum, H. M. (1973). Bias in police lineups - partial remembering. Journal of Police Science and Administration, 18, 287-293.

Elaad, E. (2013). Effects of goal- and task-oriented motivation in the guilty action test. International Journal of Psychophysiology, 88, 82-90.

Elaad, E., Ginton, A. in Ben-Shakhar, G. (1994). The effects of prior expectations and outcome knowledge on polygraph examiners' decisions. Journal of Behavioral Decision Making, 7, 279-292.

Farwell, L. A. (2012). Brain fingerprinting: A comprehensive tutorial review of detection of concealed information with event-related brain potentials. Cognitive Neurodynamics, $6,115-154$.
Farwell, L. A. in Smith, S. S. (2001). Using brain MERMER testing to detect concealed knowledge despite efforts to conceal. Journal of Forensic Sciences, 46(1), 1-9.

Fiedler, K., Schmid, J. in Stahl, T. (2002). What is the current truth about polygraph lie detection. Basic and Applied Social Psychology, 24, 313-324.

Flander, B. (2004). Poligraf [Polygraph]. Pravna praksa [Legal Practice], 23(2), 13-14.

Furedy, J. J. in Ben-Shakhar, G. (1991). The roles of deception, intention to deceive, and motivation to avoid detection in the psychophysiological detection of guilty knowledge. Psychophysiology, 28, 163-171.

Ganapati M. T., Haveripeth P. D. in Ramadurg M. S. (2013). Scientific and legal procedure of polygraph test. Journal of Bio Innovation, 2(1), 5-16.

Ganis, G., Rosenfeld, J. P., Meixner, J., Kievit, R. A. in Schendan, H. E. (2011). Lying in the scanner: Covert countermeasures disrupt deception detection by functional magnetic resonance imaging. NeuroImage, $55,312-319$.

Granhag, P. A., Strömwall, L. in Hartwig, M. (2007). The SUE technique: The way to interview to detect deception. Forensic Update, 88, 25-29.

Handler, M., Honts, C. R., Krapohl, D. J., Nelson, R. in Griffin, S. (2009). Integration of pre-employment polygraph screening into the police selection process. Journal of Police and Criminal Psychology, 24, 69-86.

Hartwig, M., Granhag, P. A., Strömwall, L. A. in Kronkvist, O. (2006). Strategic use of evidence during police interviews: When training to detect deception works. Law and Human Behavior, 30, 603-619.

Honts, C. R. (1987). Interpreting research on polygraph countermeasures. Journal of Police Science and Administration, 15, 204-209.

Honts, C. R. (2004). The psychophysiological detection of deception. V P. Granhag and L. Stromwall (ur.), Detection of deception in forensic contexts (str. 103-123). Cambridge, Združeno kraljestvo: Cambridge University Press.

Honts, C. R. in Alloway W. R. (2007). Information does not affect the validity of a comparison question test. Legal and Criminological Psychology, 12, 311-320.

Honts, C. R., Kircher, J. C. in Raskin, D. C. (2002). The scientific status of re-search on polygraph techniques: The case for polygraph tests. V D. L. Faigman, D. Kaye, M. J. Saks in J. Sanders (ur.), Modern scientific evidence: The law and science of expert testimony: Vol. 2 (str. 446483). St Paul, MN, ZDA: West.

Iacono, W. G. (2000). The detection of deception. V J. T. Cacioppo, L. G. Tassinary in G. G. Berntson (ur.), Handbook of psychophysiology (2. izd., str. 772-793). Cambridge: Cambridge University Press.

Iacono, W. G. in Lykken, D. T. (2002). The scientific status of research on polygraph techniques: The case against polygraph tests. V D. L. Faigman, D. H. Kaye, M. J. Saks in J. Sanders (ur.), Modern scientific evidence: The law and science of expert testimony, Vol.2 (str. 483-538). St. Paul, MN, ZDA: West. 
Jensen, T. M., Shafer, K., Roby, C. Y. in Roby, J. L. (2014). Sexual history disclosure polygraph outcomes: Do juvenile and adult sex offenders differ? Journal of Interpersonal Violence, 1, 1-17.

Kassin, S. M. (2008). Confession evidence common-sense myths and misconceptions. Criminal Justice and Behavior, 35, 1309-1322.

Kebbell, M., Alison, L. in Hurren, E. (2008). Sex offenders' perceptions of the effectiveness and fairness of humanity, dominance, and displaying an understanding of cognitive distortions in police interviews: A vignette study. Psychology, Crime and Law, 14, 435-449.

Kircher, J. C. in Raskin, D. R. (2002). Computer methods for the psychophysiological detection of deception. V M. Kleiner (ur.), Handbook of polygraph testing (str. 287326). San Diego, CA, ZDA: Academic Press.

Kleiner, M. (2002). Physiological detection of deception in psychological perspectives: A theoretical proposal. V M. Keliner (ur.), Handbook of Polygraph Testing (str. 127182). London, Združeno kraljestvo: Academic Press.

Köhnken, G. (2004). Statement validity analysis and the 'detection of the truth'. V P. A. Granhag in L. A. Stromwall (ur.), Deception detection in forensic contexts (str. 41-63). Cambridge, Združeno kraljestvo: Cambridge University Press.

Kosslyn, S. M., Cacioppo, J. T., Davidson, R. J., Hugdahl, K., Lovallo, W. R., Spiegel, D. in Rose, R. (2002). Bridging psychology and biology: The analysis of individuals in groups. American Psychologist, 57, 341-351.

Krapohl, D. J., McCloughan, J. B. in Senter, S. M. (2009). How to use the Concealed Information Test. Polygraph, 38(1), 34-49.

Larson, J. A. (1922). Modification of the Marston Deception Test. Journal of the American Institute of Criminal Law and Criminology, 12, 390-399.

LeDoux, J. E. (1995). Emotion: Clues from brain. Annual Review of Psychology, 46, 209-235.

Lykken, D. T. (1959). The GSR in the detection of guilt. Journal of Applied Psychology, 43, 385-388.

Lykken, D. T. (1998). A tremor in the blood: Uses and abuses of the lie detector. New York, NY, ZDA: Plenum Press.

Masip, J., Herrero, C., Garrido, E. in Barba, A. (2011). Is the behaviour analysis interview just common sense? Applied Cognitive Psychology, 25, 593-604.

Meijer, E. H., Selle, N. K., Elber, L. in Ben-Shakhar, G. (2014). Memory detection with the Concealed Information Test: A meta-analysis of skin conductance, respiration, heart rate, and P300 data. Psychophysiology, 51, 879-904.

Meijer, E. H. in Verschuere, B. (2010). The polygraph and the detection of deception. Journal of Forensic Psychology Practice, 10, 325-338.

Nakayama M. (2002). Practical use of the concealed information test for criminal investigation in Japan. V M. Kleiner (ur.), Handbook of polygraph testing (str. 49-86). London, Združeno kraljestvo: Academic Press.

National Research Council (2003). The polygraph and lie detection. Washington, DC, ZDA: The National Academies Press.
Osugi, A. (2011). Daily application of the Concealed Information Test: Japan. V B. Verschuere, G. BenShakhar in E. Meijer (ur.), Memory detection: Theory and application of the Concealed Information Test (str. 253-275). Cambridge, Združeno kraljestvo: Cambridge University Press.

Palmatier, J. J. in Rovner, L. (2015). Credibility assessment: Preliminary process theory, the polygraph process, and construct validity. International Journal of Psychophysiology: Official Journal of the International Organization of Psychophysiology, 95(1), 3-13.

Patrick, C. J. in Iacono, W. G. (1991a). A comparison of field and laboratory polygraphs in the detection of deception. Psychophysiology, 28, 632-638.

Patrick, C. J. in Iacono, W. G. (1991b). Validity of the control question polygraph test: The problem of sampling bias. Journal of Applied Psychology, 76, 229-238.

Pavlov, I. P. (1927/2003). Conditioned reflexes. Mineola, NY, ZDA: Dover Publications.

Peth, J., Vossel, G. in Gamer, M. (2012). Emotional arousal modulates the encoding of crime/related details and corresponding physiological responses in Concealed Information Test. Psychophysiology, 49, 381-390.

Podlesny, J. A. (1993). Is the guilty knowledge polygraph technique applicable in criminal investigations? A review of FBI case records. Crime Laboratory Digest, 20, 57-61.

Rachul, C.in Zarzeczny, A. (2012). The rise of neuroskepticism. International Journal of Law and Psychiatry, 35, 77-81.

Raskin, D. C. in Honts, C. R. (2002). The comparison question test. V M. Kleiner (ur.), Handbook of polygraph testing (str. 1-47). San Diego, CA, ZDA: Academic Press.

Reid, J. E. in Inbau, F. E. (1977). Truth and deception, the polygraph technique (2. izd.). Baltimore, MD, ZDA: Williams \& Wilkins.

Rosenfeld, J. P., Ben-Shakhar, G. in Ganis, G. (2012). Detection of concealed stored memories with psychophysiological and neuroimaging methods. V L. Nadeland in W. P. Sinnott-Armstrong (ur.), Memory and law (str. 263-305). Oxford, Združeno kraljestvo: Oxford University Press.

Rosenfeld, J. P., Shue, E. in Singer, E. (2007). Single versus multiple blocks of P30based concealed information tests for self-referring versus incidentally obtained information. Biological Psychology, 74, 396-404.

Saxe, L. (1991). Science and the GKT Polygraph: A theoretical critique. Integrative Physiological and Behavioral Science, 26, 223-231.

Schmid, N. (1993). Strafprozessrecht: Eine Einführung auf der Grundlage des Strafprozessrechtes des Kantons Zürich und des Bundes. Zürich, Švica: Schulthess.

Selič, P. (2009). Preverjene poligrafske tehnike - analiza [Analytical review of validated polygraph techniques]. Revija za kriminalistiko in kriminologijo [Journal of Criminal Investigation and Criminology], 60, 332-343.

Senior, C., Haggard, P. in Oates, J. (2011). A discussion paper: Neuroethics and the British Psychological Society Research Ethics Code. General Guidelines and Policy Documents, British Psychological Society. Pridobljeno s strain: http://www.bps.org.uk 
Senter, S. M., Weatherman, D., Krapohl, D. J. in Horvath, F. (2010). Psychological set or differential salience: A proposal for reconciling theory and terminology in polygraph testing. Polygraph, 39, 109-117.

Sokolov, E. N. (1963). Perception and the conditioned reflex. Oxford, Združeno kraljestvo: Pergamon Press.

Vigluicci, V. V. (2009). Calculating credibility: State V. Sharma and the future of polygraph admissibility in Ohio and beyond. Akron Law Review, 42, 319-354.

Vrij, A. (2008). Detecting lies and deceit: Pitfalls and opportunities. Chichester, Združeno kraljestvo: John Wiley \& Sons.

Walczyk, J. J., Igou, F. P., Dixon, A. P. in Tcholakain, T. (2013). Advancing lie detection by inducing cognitive load on liars: A review of relevant theories and techniques guided by lessons from polygraph-based approaches. Frontiers in Psychology, 4(14).

Weisberg, D. S., Keil, F. C., Goodstein, J., Rawson, E. in Gray, J. R., (2008). The seductive allure of neuroscience explanations. Journal of Cognitive Neuroscience, 20, 470-477.

White, A. E. (2010). The lie of fMRI: An examination of the ethics of a market in lie detection using functional magnetic resonance imaging. HEC Forum: An Interdisciplinary Journal on Hospitals' Ethical and Legal Issues, 22, 253-266. 